\title{
MXI1 Gene
}

National Cancer Institute

\section{Source}

National Cancer Institute. MXI1 Gene. NCI Thesaurus. Code C24619.

This gene plays a role in regulation of transcription and mitosis. It is also involved in terminal differentiation. 